msh-mss Mathématiques et sciences humaines

171 | Automne 2005

Varia

\title{
Fins et moyens. La théorie constructive des types considérée comme guide pour former des modèles en théorie de l'esprit et de l'action
}

On ends and means. Constructive type theory as a guide for modeling in theory

of mind and action

\section{Guido Lohrer}

\section{OpenEdition}

Journals

\section{Electronic version}

URL: http://journals.openedition.org/msh/2947

DOI: $10.4000 / \mathrm{msh} .2947$

ISSN: $1950-6821$

Publisher

Centre d'analyse et de mathématique sociales de l'EHESS

Printed version

Date of publication: 1 September 2005

ISSN: 0987-6936

Electronic reference

Guido Lohrer, «Fins et moyens. La théorie constructive des types considérée comme guide pour former des modèles en théorie de l'esprit et de l'action », Mathématiques et sciences humaines [Online], 171 | Automne 2005, Online since 10 April 2006, connection on 23 July 2020. URL : http:// journals.openedition.org/msh/2947 ; DOI : https://doi.org/10.4000/msh.2947 
Math. \& Sci. hum. $\sim$ Mathematics and Social Sciences (43 ${ }^{\mathrm{e}}$ année, $\mathrm{n}^{\circ} 171,2005(3)$, p. 5-23)

\title{
ON ENDS AND MEANS. \\ CONSTRUCTIVE TYPE THEORY AS A GUIDE FOR MODELING IN THEORY OF MIND AND ACTION
}

\author{
Guido LÖHRER ${ }^{1}$
}

\begin{abstract}
RÉSUMÉ - Fins et moyens. La théorie constructive des types considérée comme guide pour former des modèles en théorie de l'esprit et de l'action.

Cet article se propose de clarifier la relation formelle entre "fin " et " moyen 》 en termes de théorie constructive des types. Selon la tradition philosophique, deux conceptions s'opposent : l'une, machiavellienne, qui considère « fin » et « moyen » comme étant dans une certaine mesure indépendants, l'autre, kantienne, qui envisage cette relation comme analytique. La première semble inacceptable d'un point de vue aussi bien moral que logique, mais la seconde se heurte également à des difficultés. Celles ci peuvent, selon nous, être résolues grâce à la théorie constructive des types si l'on considère la fin d'une action comme le type des moyens aptes à réaliser cette fin.
\end{abstract}

MOTS CLÉS - Action considérée comme un type, Analyticité, Moyen canonique, Relation fin/moyen, Savoir pratique (savoir faire), Théorie constructive des types

SUMMARY - The following discussion aims at clarifying the formal relation between end and means in terms of constructive type theory. Philosophical tradition offers two opposed conceptions: a Machiavellian, on the one hand, dealing with end and means as to some extent independent items, and a Kantian, on the other, which regards the relation as analytical. The first seems to be both morally and logically unacceptable, but also the second one faces difficulties. I propose to resolve these difficulties along the lines of constructive type theory by considering the end of an action as the type of means which are apt to realise this end.

KEYWORDS - Actions as types, Analyticity, Canonical means, Constructive type theory, End/means-relation, Practical knowledge (knowing how)

\section{INTRODUCTION}

The distinction between ends and means constitutes one of the basic pillars both of traditional and of contemporary approaches in action theory, provided that they do not explain actions historically, i.e. focussing on previous states and events ${ }^{2}$, but rather

\footnotetext{
${ }^{1}$ University of Berne, Department of Philosophy, Länggassstr. 49a, CH-3012 Bern - Switzerland, guido.loehrer@philo.unibe.ch

2 Along these lines Bittner [2001], ch. 5 and 11, argues in favour of a historical, and indeed against a teleological view of reasons for action: "to do something for a reason is to do something that is a response to the state of affairs that is the reason" (p. 161). Thus, to act seems to be the same as to clarify a situation thus finally removing the historical reason for action, whereas, in accordance with a teleological understanding of action, a state would be reached by the realisation of an end in which this end would no longer exist. Bittner's attempt to transform any teleological explanations into historical ones is remarkable; cf. Bittner [2001], p. 152-154 (§§ 278-281).
} 
teleologically. This distinction goes back to Aristotle ${ }^{3}$ who holds that "the origin of action [...] is choice, and [the origin] of choice is desire and reasoning with a view to an end" (EN VI 2, 1139a!31-33), while "wish relates rather to the end (gr. telos), choice to what contributes to the end (gr. ta pros to telos); for instance, we wish to be healthy, but we choose the acts which will make us healthy" (EN III 5, 1111b!26-7). Therefore, "we deliberate not about ends but about what contributes to ends" (1112b!11-2), that is, finally, about means. Consequently, we draw our attention to intentions, to the procedures by which they can be realized, and, if need be, also to their consequences and side-effects, all of which are subject to action-theoretical and ethical inquiry, as well as to moral judgement and responsibility.

However, "end" and "means" are ambiguous expressions. Therefore, it is possible not only to distinguish different classes of means and ends but also to separate at least the following meanings of the expressions "end" and "means".

The term "end" denotes

1. the intended purpose of an action that we have set ourselves ${ }^{5}$, and that we pursue, because we want to attain it $^{6}$, and which we will accomplish in the successful case,

2. end in the sense of a purpose or a function which a thing or a person fulfils or is designed for, and

3. end in the sense of the purpose things or people, fulfilling a purpose in the second sense, are used for; as for instance in phrases as "for the purpose of physical training", "for the purpose of resale", and "with the aim of remaining in power".

With the word "means" we express

1. actions or modes of action which can be performed by an agent himself because they are within his reach of power and which seem apt to contribute to achieving ends of the kind mentioned under (1) above

2. instruments, things or persons which are usually used for doing so $^{8}$,

3. economical means, funds and pecuniary resources which do not show an immediate relationship to a certain goal of an action.

Although these meanings are intimately related, these modes of expression have to be distinguished. Thus, "means" in the second and third sense is directly or indirectly related to actions (means $)_{1}$ ) which for their part are directed to ends $s_{1}$ of actions, while persons and things as means ${ }_{2}$ fulfil a purpose $\left(\mathrm{end}_{2}\right)$, and economical means $\mathrm{s}_{3}$ may for instance be used to the end $\mathrm{ef}_{3}$ of bribery. Therefore, the other meanings will not be disregarded when I now focus on end as result of actions that we aim at and on means in the sense of appropriate actions which we execute to pursue these ends.

\footnotetext{
${ }^{3}$ Aristotle [1986]. For a more recent debate cf. among others Wilson [1980], Stampe [1987], Sehon [1994], and Smith [1994], p. 116-7.

${ }^{4}$ Cf. Oxford English Dictionary, 2nd ed., Oxford, Clarendon Press, 1989, vol. V, p. 220-3, and vol IX, p. 516-7. - Here, I follow Ebert [1977], p. 25-33; cf. also Hügli [1980], p. 1434-5, Kambartel [1984], p. 903, and Schwemmer [1996], p. 866-7.

${ }^{5}$ Cf. Kant [1968(e)], AK 6: 381 .

${ }^{6} \mathrm{Cf}$. Aristotle [1986], EN III 4, 1111b 26-7. That an end is something one aims at is aptly illustrated by Aristotle's image of the targeting archers; cf. EN I 1, 1094a $23-4$.

${ }^{7}$ Cf. Aristotle [1986], EN III 5, 1112b 32-3, Kant [1968(c)], AK 4: 417-8, Kant [1968(d)], AK 5: 62, and Kant [1968(e)], AK 6: 381.

${ }^{8}$ Cf., e.g., Kant [1968(c)], AK 4: 429.
} 
In the following discussion, I will try to elucidate the formal relation between the notion of end and the notion of means. Here, two contrasting conceptions traditionally arise. On the one hand, the approach associated with the name of "Machiavelli" prefers to consider end and means as rather independent items which subsequently can be linked at one's own discretion. According to the second approach, on the other hand, which can be traced back to Kant, the two notions are intimately related. (II.) Yet, the first position seems to be unacceptable not only when morally considered, but also when examined regarding conceptual logic. Nonetheless, also the second approach faces difficulties. However, as I will argue, by means of constructive type theory we are able not only to reinterpret, but also to remove such difficulties, if we understand actions or the ends of actions as types (III.) and if we succeed in introducing the notion of a canonical means (IV.). - This approach is constructive - in terms of constructive mathematics - since actions are not mapped in a world or a system of possible worlds but rather are represented within the practical knowledge of their agents. In this respect constructive action theory is a theory of mind as well as action.

\section{ENDS AND MEANS: HOLY ALLIANCE OR ANALYTICITY?}

An act or a way of acting seems to be suitable for a great variety of purposes. And skill in the use of means to all sorts of arbitrary ends is of advantage ${ }^{9}$. An end can be realized in abundant ways. Only those who deem the correctness of an action more important than its outcome will be scrupulous, as Baltasar Gracián suggests in $1647^{10}$. For, as he condescendingly claims, they ignore that, generally, the victorious need not account for their deeds and that with the fortunate result the dubious means will be forgotten ${ }^{11}$. Here we deal with the advice to consider actions exclusively according to the question whether they are sufficient means to a given end or not ${ }^{12}$. Regarding a given end the order reads: Choose only such acts that will reliably bring about a desired state! In reference to the deliberation on ends one can hold: Choose only such ends which are reliably realizable for you! $!^{13}$

However, as a rule this kind of prudence is tied up with certain conditions, at least by its more subtle advocates. For the justification of actions it is not enough to suppose them to be sufficient means. They also have to prove to be necessary means whose execution is justified if the aim is good. If means and ends retain the considered kind of mutual independence, then, as the opportunist maintains, a morally good end may be realized by a morally objectionable means which is finally if not approved, still excused, provided that it has been the only way to realize the good. Machiavelli argues

\footnotetext{
${ }^{9}$ Cf. Kant [1968(c)], AK 4: 415.

${ }^{10}$ Cf. Gracián [1995], p. 138 (\$ 66).

${ }^{11}$ For a comparable argument encouraging unscrupulousness cf. Machiavelli [1999], p. 301-2 (ch. 18): "E nelle actione di tutti li uomini e maxime de' principi, dove non è iudizio ad chi reclamare, si guarda al fine. Facci dunque uno principe di vincere e mantenere lo stato: e mezi sempre fieno iudicati onorevoli e da ciascuno saranno laudati".

${ }^{12}$ See the role of sufficient means for the abductive method of the Aristotelian practical syllogistic; cf. Aristotle [1968], De motu animalium 7, 701a 16-24, and [1986], EN VIII 5, 1147a 5-7, 29-31. Here, practical reasoning immediately leads to the execution of an action. To avoid the coerciveness of such a consequence, more recent literature in the theory of action distinguishes between immediate intentions and standing intentions; cf. Audi [1997], p. 179-80, and Mele [1992], p. 145.

${ }^{13}$ Brentano [1955], p. 15, formulates similar rules. In addition, for the choice of ends he sets the rule "Choose the best from what is realizable!" (p. 16, my translation), which, for an appropriate understanding, has to be supplied with a moral psychological investigation into the concept of the good.
} 
along these lines in favour of Romolus' homicide of his brother, since it was the only way to secure a monocratic regime for the young Roman state which Machiavelli supposes to be absolutely necessary in the beginning for both the promotion of the public good and the fortunate development of a polity ${ }^{14}$. Obviously, this seems to be the case to which the saying "the end justifies the means" refers. The goodness of the end is supposed to justify the means if the means is not only sufficient but necessary, that is, it would not be possible to attain the end otherwise.

This point may be satirically overdrawn by Pascal's description of a would-be Jesuit moral. Pascal presents the matter as if it were the task to subsequently find a justifying end for a bad means, so that the means enters, as it were, a holy, or rather a sanctifying alliance. Thus, for instance, the means of the duel, which is in itself objectionable, is morally bad if used as a means to the end of revenge, but it is good as the defence of honour. So whoever wished to retain the practice merely had to exchange the end ${ }^{15}$.

However, this position not only renders end and means completely independent, but also inverts the task of deliberation. Under these auspices, deliberation would no longer be considered as the task to find the means to a given end. Instead, deliberation would rather assign an end to a given means which before either had no end at all or followed a different end. This is supposed to be in conflict with the reading that "means" is a relational notion and would transform the end into a sort of superstructure for another aim which is suppressed within the analysis of the action.

Absurdity and difficulties of this kind can perhaps be avoided if we appropriate the Kantian analysis of the relation between end and means. "Whoever wills the end", an often quoted passage from the Foundations of the Metaphysics of Morals runs ${ }^{16}$,

also wills (insofar as reason has decisive influence on his action) the indispensably necessary means to it that is within his power. This proposition is, as regards the volition, analytic [...].

Yet, at first glance this appears dubious. For, as it is well known, sentences in the scope of volitional or intentional attitudes, as well as such that appear in the scope of the attitudes of belief, knowledge, or hope, form an intensional and so-called opaque context $\mathrm{t}^{17}$. Here one cannot exchange in general a singular term salva veritate by a codesignative term ${ }^{18}$, since it must remain uncertain whether the coreferentiality of the

\footnotetext{
${ }^{14}$ Cf. Machiavelli [1999], p. 479 (Discorso I 9): "Però uno prudente ordinatore d'una republica e che abbia questo animo di volere giovare non a sé ma al bene comune, non alla sua propria successione ma alla comune patria, debbe ingegnarsi di avere l'autorità solo. Né mai uno ingegno savio riprenderà alcuno di alcuna attione strasordinaria che per ordinare uno regno o constituire una republica usasse. Conviene bene che, accusandolo il fatto, lo effetto lo scusi; e quando sia buono come quello di Romolo, sempre lo scuserà; perché colui chi è violenta per guastare, non quello che è per racconare, si debbe riprendere." ("It is well that, when the act accuses him, the result should excuse him; and when the result is good, as in the case of Romulus, it will always absolve him from blame").

${ }^{15}$ Pascal [1992], p. 116: "Ce n'est pas qu'autant qu'il est en notre pouvoir nous ne détournions les hommes des choses défendues; mais purifions au moins l'intention; et ainsi nous corrigeons le vice du moyen par la pureté de la fin." These remarks surface in Molière's Tartuffe, act 4, scene 5, vv. 1429-30: "[...] et de rectifier de mal de l'action / Avec la pureté de notre intention."

${ }^{16}$ Kant [1999], AK 4: 417. See also the contraposition in Fichte [1976], p. 306: "wer das Mittel ausschlägt, wenn er es bedarf, gibt den Zwek auf" ("who refuses the means when he needs it abandons the end", my translation).

${ }^{17}$ Cf. Burri, Freudiger [1990], p. 100.

${ }^{18}$ Quine [1981], p. 151, points to the referential opacity of the intensional context: "An opaque
} 
terms in question is known to those who have the volition in question. Thus, it may be that Peter wants to become an oculist without willing to become an ophthalmologist, if the meaning of the latter word is not known to him ${ }^{19}$. A further objection is supposed to consist in the fact that to want an end may entail the volition of conflicting means which finally would neutralize each other ${ }^{20}$.

That, contrary to the first impression, both problems do not arise in Kant is due to the clause "insofar as reason has decisive influence on his action". For this clause determines the meaning of the expression "to will" in such a way that it turns into a question of a volition to which the reason of the willing person assigns an adequate means. Hence, the volition will be fully determined by a rational end/means-relation ${ }^{21}$. In that capacity the volition is, then, as Kant emphasizes, distinguished from a wish. Since a wish aims at a state, but does not pursue its realisation, the mere wish lacks the intention to employ means ${ }^{22}$.

Thus the sentence in question is indeed analytical ${ }^{23}$. For it fulfils all criteria which Kant states for analytical judgements ${ }^{24}$. Firstly, the notion of willing an end entails or even comprises, as it were, per definitionem the notion of a corresponding volition of a means. Secondly, the judgement which discloses this relation, which makes it explicit, is an explicative judgement (Erläuterungsurteil). For it contains everything needed to make it evident to oneself. And, finally, under these auspices it is by contradiction impossible to will an end and not to will the indispensably necessary means to it at the same time. There is a connection between the generation of an end and the idea of an attainment of this end. Otherwise we would deal with a mere wish ${ }^{25}$.

Nevertheless, there remains the difficulty whether talking of an "indispensably necessary means" appeals to a distinction between necessary and sufficient means, on

construction is one in which you cannot in general supplant a singular term by a codesignative term (one referring to the same object) without disturbing the truth value of the containing sentence".

${ }^{19}$ The example is due to Burri, Freudiger [1990], p. 100.

${ }^{20}$ Cf. Seel [1989], p. 162-165, who in this context refers to Kant's notion of Realpugnanz in Kant [1968(a)], AK 2: 172.

${ }^{21}$ Cf. Patzig [1971], p. 121, uses the notion of a rational will which is supposed to bridge the gap between the volition of the end and the volition of the means. - Searle [2001], p. 242-257, alerts not to expect too much from practical reasoning. With regard to Kant's doctrine in [Kant 1968(c)], AK 4: 417, he demonstrates that practical reasoning cannot be interpreted along the lines of a desire/belief model, for it would always be possible that certain actions, although being apt to fulfil a desire, will not, however, be taken into consideration. Thus, suicide would not be an a willing we would be committed to, even if it were the unique means to get rid of an influence ([Searle, 2001], p. 264). Here, admittedly, we have to account for Frederick Schick's more subtle analyses and proposals, amplifying an explanation in terms of desire and belief by the factor understanding; cf. Schick [1991, 1997]. For this cf. also the moral psychological considerations on care and on what we regard as important to ourselves in Frankfurt [1999, 2004]. - Searle's counter example to Kant in [Searle, 2001], p. 265, seems to be beside the point, for acute pain is not at all a means for a dental treatment.

${ }^{22}$ Cf. Kant [1968(c)], AK 4: 394, and Prauss [1989], p. 22-3. - In this respect "to will" means "the summoning of all means insofar they are in our control".

${ }^{23}$ Seel [1989], p. 165, and Burri, Freudiger [1990], p. 101, reach the same result. - I shall not touch upon the question whether Kant is right to derive an obligation to the volition of the means from the volition of the ends in hypothetical imperatives (which he probably is not). Kant [1999], AK 4: 417: "the imperative extracts the concept of actions necessary to this end merely from the concept of a volition of this end"; cf. AK 4: 419 u. AK 4: 444. Cf. the unexpected positive assessment of Kant's assumption in Searle [2001], p. 266.

${ }^{24}$ Cf. Kant [1956], A 6-7, B 10-1; A 150, B 189-90, and [2004(b)], AK 9: 111 (§ 37). Cf. for this Löhrer [2002], p. 64-70.

${ }^{25}$ Recently this consideration was restated and defended by Harman [2000], cf. p.123. 
the one hand, or, according to a more intuitive understanding, to a distinction between indispensably required means and arbitrary ones, on the other hand. For the present it is not yet clear what the latter should mean. But also the volition of exclusively necessary means seems to be an insufficient qualification. For, if the means which are co-intended with the end were not acts which will entirely realize the end ${ }^{26}$, with regard to the volition of an end, it would already be clear that this end could be realized at most partially, even when the action is not thwarted by another impact. This would show a tendency to undermine the analyticity relation between the volition of an end and the volition of means. Willing and wishing would not be categorically distinguished. On the contrary, wishing would have to be regarded as a zero grade (Schwundstufe) of willing. In order to avoid misunderstanding of this kind, Husserl elucidates this point in his lecture courses on Ethic and Value Theory (Vorlesungen über Grundfragen der Ethik und Wertlehre) from 1914:

Each volition is directed at an aim, and with the idea of an aim it is given, and necessarily included, to be the end of a path towards this aim. The will towards an aim is necessarily a will towards an aim in terms of a path ${ }^{27}$.

However, if the indispensably necessary means would entail that each one of it were a sufficient one, then the problem would arise that there can be more than one necessary means. Since by virtue of the rationality condition for volitions these means would not neutralize one another, the analyticity of end and means volition would compel one to execute all of these acts. This is absurd. For in conclusion, the success of merely a single strategy could obstruct the achievement of the end altogether ${ }^{28}$.

I will give a simple example: When there are two pieces of chocolate on a plate and the task is to eat one and to leave one, then this can be fulfilled by eating one or the other piece of chocolate. As opposed to this, the successful execution of both strategies would obstruct the achievement of this end.

These findings were supposed to explain why Kant speaks of an "indispensably necessary means" in the quoted passage, using a singular form ${ }^{29}$. If to the volition of an end the volition of a uniquely possible and, therefore, necessary and sufficient means is assigned, then the relation between them is a mutually analytical one. Thus, it would also hold that whoever wills the indispensably necessary means to an end also wills the end which is realizable by it, and whoever wills the path also wills the aim. This may be clarified by an example in which Kant emphasizes that synthetic judgements are required to determine the appropriate means for an end. In order to divide a line into two equal parts, for instance, analysing the purpose will not furnish me with a method that allows for the realization of this purpose. Few lines further on, Kant continues:

That in order to divide a line into two equals on a sure principle I must take two intersecting arcs from its ends, mathematics admittedly teaches only by synthetic propositions; but when I know that only by such an action can the

\footnotetext{
${ }^{26}$ Hügli [1980], p. 1436: "To leave the house is a necessary condition to reach the station, but by fulfilling this condition I have not yet reached the station" (my translation).

${ }^{27}$ Husserl [1988], p. 52. Hügli [1980], p. 1433-4, points out that in this context the notion of path was introduced already by J.A Eberhard, though without success. In recent theories of action the term "path" plays an important role; cf. Segerberg [1985], p. 328, and [1996].

${ }^{28}$ Cf. Chellas [1995], p. 566, and Segerberg [1996], p. 66-7.

${ }^{29}$ Kant [1968(c)], AK 4: 417. As also later in the Groundwork, AK 4: 417, Kant uses plural forms when happiness is the considered end. - The English translations render Kant's use of singular with plural, too. Cf. Kant [1978], p. 39, [1983], p. 27, and [1999], p. 28.
} 
proposed effect take place, then it is an analytic proposition that if I fully will
the effect I also will the action requisite to it $[\ldots]^{30}$.

Here, the intention is expressed by a synthetic sentence, and even by a thorough analysis of this intention the procedure by which it could be realized cannot be found. In order to make clear how the intention can be realized and, at the same time, to point out that we are concerned with a volition, and not with a wish, we have to go beyond what is contained within the judgement. However, if we have gained possession of a means by an augmentative judgement (Erweiterungsurteil), the judgement which assigns the means to the end will in turn be analytical. It entirely fulfils the criteria which Kant states for judgements of this sort. In addition, the knowledge which is thus obtained ensures transparency of the intensional context. Since it is knowledge of a sure principle, the adherence to which will uniquely answer for the realization of the end, the volition of the end will prove to be volition of the means as well as the volition of the means to be volition of the end. If the finding of a mutual analyticity is sound and if the example holds as a pattern (although Kant might not have intended this) ${ }^{31}$, then means and end are intimately related, not only formally considered, i.e. with regard to conceptual logic, but also with regard to their respective content, so that arbitrary manipulative combinations will inevitably be ruled out.

However, we obviously deal here with a kind of analyticity which Kant himself rejected as an epistemic possibility, namely with analyticity a posteriori. Since the procedure does not necessarily require experience, a translation of a posteriori presents itself not with the phrase "obtained by experience" but rather "from the latter". Analyticity a posteriori is retrospective analyticity. - If I understand correctly, this notion thus corresponds to that kind of analyticity which was introduced by Per MartinLöf for type theory in [Martin-Löf, 1994].

Now, as Antony Flew observed, talking of ends as justifying means presupposes that one and the same aim can be achieved by different methods, and that the problem is to find some way to reach it, or to select one or the other of various alternative routes, all of which lead to the same place; just as climbing up a hill may be accomplished either by sticking to the path or by walking cross-country. This assumption does not hold if the means affect the end to such an extent that different paths will lead to different aims ${ }^{32}$.

These considerations contain further problems. If it were no longer possible to separate end and means, everything would appear to be done for its own sake, which would not only raise the question how classical situations of self-defence have to be judged. Already a surgery carried out in order to cure a patient would lack an appropriate explanation by this paradigm. Yet, the defensive move suggests that

\footnotetext{
${ }^{30}$ Kant [1999], AK 4: 417.

${ }^{31}$ In a private discussion Gerold Prauss argued that, by rights, Kant would have had to revoke his dictum about analyticity in the case in question (Kant [1968(c)], AK 4: 417). - In fact we are here concerned with a case of analyticity which, as it were, has to be produced. Therefore, it represents something close to an analyticity ex post, i.e. a kind of judgement that Kant's thought did not provide, namely, an analytical judgment a posteriori. For this cf. Kant [1956], B 11-2, and [1968(b)], AK 4: 267.

${ }_{32}$ Flew [1967], p. 509-510: "Talk of ends either justifying or not justifying means, of achieving good ends by evil means, and so forth, presupposes that we are dealing with something analogous to a field game in which the objective is unitary and given. The problem is to find some way to reach it, or select one or another of various alternative routes, all of which lead to the same place. [...] In ethics the means used will usually affect the end achieved; the different routes most often lead to different places".
} 
objections of this kind are just evidence for the view that means are supposed to be conceived of as a set of basic actions, which is neutral with respect to any end and can be applied to achieve arbitrary ends. Instead of this, one has to distinguish between a surgical cut and a butcher's cut. However, this would finally amount to a one-to-one relation of end and means. Then, on the one hand, the end will sanctify the means at most in that trivial sense that per definitionem alternative means are not available. On the other hand, things would probably become extremely tangled, in particular when we examine not only single actions but traces or sequences of concerted actions.

The mentioned difficulties evoke once more the question of an apt understanding of the end/means-relation while equally calling for an approach that would help to avoid the questionable points.

\section{ACTIONS AS TYPES}

Martin-Löf's constructive type theory follows Haskell B. Curry and W.A. Howard in considering propositions not as truth values, but as interpreted types ${ }^{33}$. Curry's discovery builds on the insight that an implication $A \quad B$ can be read as a function type $A^{\prime} \square B^{\prime}$, while $A^{\prime}$ and $B^{\prime}$ are interpretations of $A$ and $B$. A proof of the implication $A$ $B$, therefore, can be understood as a function which takes a proof-object of $A$ into a proof-object of $B$, that is, as a higher-order function which deals with a lower-order function $^{34}$. In type theory this point of view is bound up with Heyting's explanation of the proposition as the expectation of a fulfilment (Erfüllungserwartung) that can be fulfilled, or is realizable, by certain objects. In this theory, a proposition is considered as a type: the type of its truth-making proof-objects ${ }^{35}$.

A type is defined by laying down what one has to do to construct an object of the type in question and when two such objects are equal ${ }^{36}$. If propositions are types, the following inference rule holds analytically ${ }^{37}$.

$$
\begin{array}{ll}
\text { A!:!prop } & \text { If } A \text { is a proposition, then the proof(-object)s of } \\
\text { proof }(A) ! ! \text { type } & \text { proposition } A \text { form a type. }
\end{array}
$$

Nordström, Petersson and Smith who intend type theory to be a theory for program construction interpret this scheme:

If $A$ is the specification of a program problem, then the programs that will resolve the specification problem A form a type.

Or, as they put it:

A specification is in type theory expressed as a set, the set of all correct programs satisfying the specification. The programming process is the

\footnotetext{
${ }^{33}$ Cf. Curry, Feys [1958], p. 10 and p. 24. Here, Curry informally interprets the principle by the idea that a type is a category of objects and a proposition is a category in this sense. Cf. Howard [1980], p. 479 (informal). Howard's theory is an extension of Curry's, accounting not only for implications but for any operations performed with logical connectives.

${ }^{34}$ Cf. Curry, Feys [1958], p. 312-5.

${ }^{35}$ Cf. Martin-Löf [1984], p. 6, and Ranta [1994], p. 41.

${ }^{36}$ Cf. Martin-Löf [1975], p. 76, and [1984], p. 8, 21.

${ }^{37}$ Cf. Sundholm [1998], p. 195 n. 17.
} 


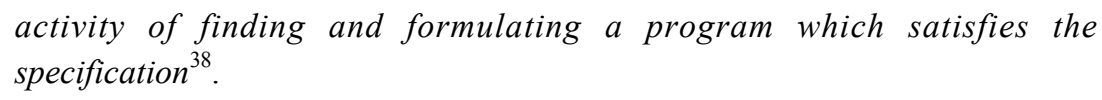

Starting from here, it seems to be only a small step to the assumption that

If $A$ is the end of an action, then the means to realize the end A form a type ${ }^{39}$.

At the least, this would be valid for such actions by which an agent brings about a certain state. Thus, our scheme could count as a constructive version of Krister Segerberg's representation of an action by a term " $\square A$ ", which consists of a formula or proposition $A$, representing the end-state of an action, and an operator $\square$ which denotes the set of (qualified) paths or routines successfully arriving at this very state ${ }^{40}$. And since for determining what an action is we have to examine the successful case, to execute $A$ means to bring about a state $A$ by engaging those routines - available in the repertoire of an agent - which will reliably terminate in a state $A$.

Lete me explain this in more detail:

In order to see how an action should be understood, it often will be convenient to look at what is demanded from an agent who wants to perform that very action. And this may also become clear by examining what entitles a speaker or commander - apart from legitimate authority - to give certain orders. Aarne Ranta has specified two rules for this, namely the rule for the recipient of orders (hearer)

(!) React to the instruction !A by making $A$ true, that is, by producing an object of type $A^{41}$,

and the corresponding rule of fairness concerning the commander (speaker)

(!') You may give the instruction !A if the reader is able to produce an object of type $A^{42}$.

The order $! A$ requests an agent to adopt the end $A$ and to perform whatever will bring about this end. Considered as something to be made true, the end of an action is a

\footnotetext{
${ }^{38}$ Cf. Nordström, Petersson, Smith [1990], p. 4. - As an anonymous referee rightly complained, speaking alternatively of types and sets is too casual, since requirements for the formation of elements of sets are stricter than those for the formation of the objects of a type. Jacobs [1989], p. 404: "An important difference is that sets are better known than categories [types]: an assertion that $A$ is a set presupposes that $A$ is very well known so that enough information concerning the elements is presented in order that quantification over $A$ makes sense [...]. In general our knowledge of categories [types] does not suffice to quantify over them in an understandable way. The differences between categories [types] and sets stem from the difference in knowledge about the formation of their objects c. q. elements".

${ }^{39}$ For the following see also Löhrer [2003], p. 322-335.

${ }^{40}$ Cf. Segerberg [1985], p. 187-8, [1989], p. 327, and [1996], p. 63. Along with Segerberg other PostDavidsonian theorists of action have done a lot of fruitful work in formalization and have developed as powerful instruments as the stit-theory ("seeing to it that"). Cf. Horty [2001] and Belnap, Perloff, XU [2001]. I deal with these accounts in Löhrer [2003], ch. 2 and ch. 3.

${ }^{41}$ Ranta [1994], p. 143.

${ }^{42}$ Ranta [1994], p. 143. Ranta speaks of a "reader" because he has the user of a cookery-book in mind who, by his lecture, receives the instruction for the preparation of a certain meal. The indicated situation is anything but univocal and straightforward. It presupposes a reader who is disposed to receive instructions and to act according to them instead of merely drawing his culinary inspiration from leafing through a cookery-book. At first, the reader has to bring about the situation in which he is the addressee of an instruction. On the other hand, the author of a cookery-book does not know his readers. Thus, he only demands what one can commonly, and with complete justification, expect from a reader, all the while distinguishing between instructions for beginners and for experts.
} 
state of affairs, represented by a proposition ${ }^{43}$. This proposition is not by itself true (or false). Rather, its truth has to be brought about expressly by an agent.

If $A$ becomes realized by an agent producing an object of the type $A$, the end $A$ is considered as the type of objects by which this end is realized. Thus we get an end-astype-principle.

If ends are types, this will be reflected in a judgement of the form

$$
\text { end!:!type ends form a type. }
$$

end!:!type is a general action theoretical or meta-theoretical claim - the fundamental thesis that ends form types. Further, this means that the objects of an end type $A$ form this very type:

$$
\operatorname{object}(A) !: ! y p e \quad \text { The objects of } A \text { form a type. }
$$

The type means $(A)$ is given, not empty, existent etc., as soon as we know that $A$ is an end. If ends are types, the following inference rule holds analytically:

$\frac{A !: ! e n d}{\text { means }(A) !: ! \text { type }} \quad$ If $A$ is an end, then the means bringing $A$ about form a type.

You have the right to judge end!:!type, if you know an object of this type or, respectively, if you are provided with the knowledge which entitles you to make a judgement of the form

$$
A \text { !:!end } \quad A \text { is an end. }
$$

$A !:$ !end is a deliberative judgement which asserts that $A$ is the type of means to bring $A$ about. If $A$ is an end, then $A$ is realizable, provided that the type $A$ has an object. Hence, the judgement $A$ !:!end expresses the expectation that the intention given with $A$ can be fulfilled. The expectation is justified or correct if the judging agent knows the type of means that makes $A$ true or causes $A$ to happen. A person who correctly judges $A !: ! e n d$, knows what is required to bring $A$ about. She has grasped the problem or task which has been posed by $A$. In inverted order the precedent considerations can be represented as follows:

\footnotetext{
${ }^{43}$ Even Robert Jeffrey's theory, which is geared to the concept of proposition used in propositional logic of possible worlds, describes acting as rendering propositions true. However, here the proposition describing the end of an action finally does not count, since any proposition which comes true by an action is equally considered, whether it has been brought about intentionally or not. Jeffrey [1983], p. 218: "When you act in accordance with your preferences, you enact a certain proposition: one of the highest-ranking among those of your options which you believe to be options. You enact the proposition $A$ (or, equivalently, you make the corresponding sentence true) by performing some perfectly definite act - an act which can be described as making $A$ true, but which can also be described truly as making any member of other propositions true. Among all these, it need not be obvious either to the agent or to an observer, which is the proposition for the sake of the truth of which the act was performed." The elements of this set theory model are named in: Jeffrey [1983], p. 226. Cf. already Jeffrey [1974], p. 382-3. In relation to the corresponding desires and wants, the preferences shed light on an agent's rational motive to perform a certain action. However, the model is not able to provide any information about the appropriateness (correctness) of the action and its performance; cf. Jeffrey [1983], p. 216.
} 


\begin{tabular}{c}
$(x !: ! A)$ \\
। \\
A!:!end \\
\hline A!:!type \\
\hline end!:!type
\end{tabular}

Provided that there is a hypothetical means given in a hypothetical judgement " $x$ brings about that $A$ ", $A$ is an end. Since the objects of $A$ form a type and $A$ is hypothetically not empty,

$A$ is a type. Since $A$ is an end, ends form a type. The type of ends is not empty.

On the condition that the end of an action is understood, it is possible to explain the form

$$
a !: ! A \text {. } \quad a \text { brings about that } A \text {. }
$$

Here we have both end and means within the same formalism. The knowledge which is expressed here is practical knowledge. An agent is provided with the practical knowledge or the ability to bring about that $A$, if he is provided with a means by which she can bring $A$ about. She not only knows the type of the truth-makers of $A$, but also knows an object of this type and hence a procedure by which to bring $A$ about. This is named knowing how or practical knowledge. So far the explanation of $a !: ! A$ remains within the field of deliberation.

An action, in the narrow sense, is represented by the form $a !: ! A$, if the agent translates her practical knowledge into practice, that is, when she produces an object $a$ of type $A$, that is, a means which realizes the end $A$, if there is no impediment and the action is not foiled. When an end $A$ is brought about by a means $a$, it disappears as an end. $A$ becomes a proposition which is now assertable for an agent, since her practical knowledge can be turned into theoretical knowledge. Whoever knows that she brought about $A$, also knows that $A$ is true. Whoever follows the rule ${ }^{44}$ :

Respond to !A by acting so that you may utter $\square A$

by producing an object of type $A$ and, hence, rendering $A$ true, is also entitled to judge $A$ is true. The knowledge that $A$ was accomplished is here equated with the knowledge of how $A$ was accomplished. The difference between knowing that and knowing how will then be removed in type theory ${ }^{45}$. Whoever knows what is to do (A!:!end) (knowing what to do) and knows how to do it ( $a !: ! A)$ (knowing how to do), also knows that she has brought about $A$ by translating her practical knowledge into practice. Therefore she may now assert that $A$ is true (knowing that).

Action cannot be transformed further than into the form of $a !: ! A$. In the case of theoretical judgement it must be assumed that it is possible to recognize a proof-object of a proposition "when presented with one"46. In the case of deliberation we must assume that it is in principle possible to recognize that something is a means to an end. As our experience shows, practice is always conducive to error and failure, but this does not invalidate the capacity to act at the moment when an agent knows of a means.

When we draw a parallel to the forms of judgement introduced by Martin-Löf, then in case of the form $a !: ! A$ we deal with a categorical form of action. In the case of

\footnotetext{
${ }^{44}$ Ranta [1988], p. 388.

${ }^{45}$ Cf. Martin-Löf [1996], p. 36.

${ }^{46}$ Dummett [1977], p. 6.
} 
deliberate action, however, every action $a !: ! A$ depends on a judgement $A !: ! e n d$, so that the entire form is to be noted:

$$
a !: ! A(A !: ! e n d) \quad a \text { brings about that } A \text {, provided that } A \text { is an end. }
$$

In type theory objects are always objects of a certain type. Necessarily, there is an identity criterion for every type consisting of an identity relation between its objects. ${ }^{47}$ Two objects $a$ and $b$ are semantically or definitionally identical if they are equal objects of the same type: $a !=! b !: ! \square$. Therefore, in addition to the hitherto mentioned form there are the forms of identity judgements which are important for the deliberation process:

$$
A !=! B !: ! e n d \quad A \text { and } B \text { are equal ends, }
$$

where $A$ is an end and $B$ is an end, so that the explicit judgement is:

$$
\begin{aligned}
A !=! B !: ! \text { end }(A !: ! \text { end, } B !: ! e n d) & A \text { and } B \text { are equal ends, provided that } A \text { is an end } \\
& \text { and } B \text { is an end, }
\end{aligned}
$$

and

$$
a !=! b !: ! A \quad a \text { and } b \text { are equal means for } A \text {, }
$$

where it is presupposed that

1) $A$ is an end

and that

2) $a$ and $b$ are means to bring about $A$,

so that the explicit form of judgement is:

$$
\begin{aligned}
& a !=! b !: ! A(A !: ! e n d, a !: ! A, b !: ! A) \quad a \text { and } b \text { are equal means for } A \text {, provided that } A \text { is an end } \\
& \text { and } B \text { is an end. }
\end{aligned}
$$

Two ends $A$ and $B$ are equal if they can be realized by the same means. If it is known that $A$ is an end and that $B$ is an end, then:

$$
A !=! B !: ! \text { end } \quad A \text { and } B \text { are equal ends }
$$

means

1. that if $a$ is a means which brings about that $A, a$ is also a means to bring about that $B$, and vice versa, and

2. that if $a$ and $b$ are equal means with regard to the realization of $A$ (i.e. equal objects of type $A$ ), then $a$ and $b$ are also equal means with regard to the realization of $B$ :

$$
\frac{a !: ! A}{a !: ! B} \quad \frac{a !=! b !: ! A}{a !=! b !: ! B}
$$

In the theoretical realm it is essential for the explanation of the judgemental forms as well as for the explanation of the logical constants (in a type theoretical interpretation

\footnotetext{
${ }^{47}$ Cf. Sommaruga [2000], p. 71.
} 
of the introduction rules), to rely on canonical proof-objects. Conversely, it seems at least doubtful whether there is an equivalent to this in the practical realm. Are there canonical means? Does a normal form of means exist? Something of this kind seems to be requested in order to consider a judgement of the form:

$a !=! b !: ! B(B !: ! e n d, a !: ! B, b !: ! B)$

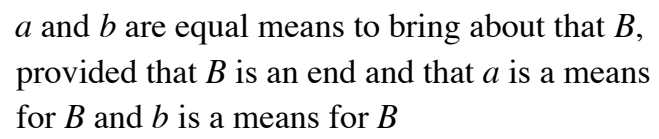

to be a transformation of a non-canonical means $a$ into a canonical means $b$. Judgements of this form have to be made, since the greater number of ends can be realized in more than one way. A critical judgement is necessary in order to decide whether a certain procedure can ever be a means to a given end. Thus, canonical means or procedures would count as a judgemental pattern.

\section{CONCLUSION: COMME IL FAUT - A CRITERION TO JUDGE END/MEANS- RELATIONS}

I will now reconsider the problem that arises from Kant's thesis of an intimate formal relation between end and means.

If the end of an action is supposed to be an aim which can be attained by certain means and if the volition of means is given by the volition of an end, then it seems appropriate to understand the end as a type, namely as the type of those means by which the end can be realized. Thus we obtain an end-as-type-principle. If something is an end, then the act realizing this end is an object of the type of this end, namely an object of the type of the means realizing this end. This type is not empty - or, in Kant's words, not just the object of "a mere wish but as the summoning of all means insofar as they are in our control"48 - if there is at least one means falling within its scope, that is, that a person who desires this end is able (and willing) to perform an action being an apt means to realize this end. To deliberate is to search for an object of the type in question.

The fact that the end - considered as a propositional structure - is something intensional distinguishes it from the extensional result of the act. It is not only the case that the end of an act ceases to be an end when it is accomplished, while at the same time the result in the sense of a state (of affairs), event or process is lasting ${ }^{49}$. It would also be strange to charge the result with similar analytical relations as the end, as if it were provided with means.

Although it is not possible to reach the required means for the realization of a certain intention with an analysis of this intention, an adequate understanding of the intention should allow for identifying the necessary means. Since to know which means are needed to attain the end of an action is equally to know what it is to perform an action of this kind. This suggests, moreover, an understanding of the end of an act as a precept by which the necessary and sufficient means for its realization can be found

\footnotetext{
${ }^{48}$ Cf. Kant [1999], AK 4: 394.

${ }^{49}$ Ebert [1977], p. 35: "One is in possession of an end only as long as it is not yet achieved. With their achievement ends 'disappear', and this implies nothing else but that speaking of 'ends' is only meaningful for the interpretation of actions which at any rate cannot be situated after the achievement of the end." (My translation).
} 
(and carried out). Thus, an end would be interpreted as a precept or task to find the appropriate means, whereas the means are possible solutions or fulfilments of this task or precept, respectively. They will specify the end. Through them it becomes intelligible what it means to have this end.

In general there is more than one way of bringing something about. But certain ways of acting will no longer be considered as pursuing one and the same end. For a critical deliberative judgement, i.e. in order to tell deviating from devious or incorrect acts, a criterion or a standard is required. In many cases this standard should be close at hand. For numerous ways of acting receive their meaning by virtue of seemingly canonical means (routines) whose employment would amount to a correct execution of the respective actions. There is a comme il faut by which it is laid down in an idealized, yet executable way what it means to do this or that. This gives meaning to a way of acting and renders it identifiable. This is the way it is taught and learned, it has proved good and is continuously confirmed. Thereby a meaning-determining deontic feature is addressed, the content of which may well be obtained by experience and interactive trial (Bewährung) rather than by pure practical reason.

Firstly, the notion of a canonical means is fundamental or primitive and thus can neither be evaluated any further nor is it definable by reverting to something even more fundamental. When presented with a canonical means, one should immediately recognize that this is a means to a respective end. Secondly, in order to be judged as non-canonical, a means which does not possess the canonical form must be transformable into its canonical form:

$a !=! b !: ! A(A !: ! e n d, a !: ! A, b !: ! A)$.

Otherwise, we are not dealing with a means to the respective end.

Admittedly, if any transformation of a non-canonical form into a canonical one needs to be a mechanical calculation, this procedure would be restricted to mathematics. However, let us consider for example an action which is very common to us academics: to give a reference for a quotation. "[T]he glove of one hand cannot be used for the other", is an expression from Kant's Prolegomena ${ }^{50}$. Here, the canonical way to give evidence will be to give reference to an authoritative edition: Kant's works, issued under the auspices of the German Academy, volume 4, page 286 (= AK 4: 286), even more precise: lines 19-20 (= AK 4: $286_{19-20}$ ). This means is primitive and cannot be further evaluated. It determines what it means to give reference to Kant's writings, that is, a canonical means is one in terms of which meaning is given to the notion of a certain action.

Yet, we could make our reference also in a non-canonical way: We find Kant's sentence quoted with another author and prove it through this secondary source. This procedure should allow to find the original phrase in Kant's writings again. This would help to give canonical reference when requested. In this respect proving through a secondary source is a non-canonical means through which a canonical means can be found. Nevertheless, only the canonical reference allows to tell a secondary quotation from a free invention, imputing strange remarks on gloves to Kant. It is only in this way that those cases of armchair travel can be revealed where one author copies the faults of another, without ever consulting the sources.

${ }^{50}$ Kant [2004(a)], AK 4: 286. 
This point is remarkable. For it provides us with a notion of correctness concerning the relation between means and end, without committing us to a one-to-one relation, since the latter seems to be grotesquely false: it would compel us to assign even slightly diverging means or acts to different ends. Instead of this, the notion of a canonical means enables us to judge a deviation perhaps as a roundabout but nevertheless correct variant of a comme il faut way of acting.

On the other hand, the mentioned meaning determining feature would allow for reasonable restrictions of the means-to-ends assignment. If a way of acting can no longer be considered as a non-canonical but nevertheless correct variant of an action comme il faut, since its means cannot be evaluated into a canonical one, then (but only then) it seems reasonable to assume that the act in question is mistaken or that it is used to pursue an entirely different end.

Not the mere success but the means determines the action. To check whether the intended result of an action (as an end) is correct, one has to scrutinize whether it was brought about correctly ${ }^{51}$. In this respect the notion of a canonical means, i.e. a canonical object of a type $A$, provided that $A$ is an $e n d$, is not an instrument for obtaining all the objects of this type ${ }^{52}$, but rather a tool for discerning correct means to a respective end from merely putative ones ${ }^{53}$. If someone does not accept that we are dealing with a certain action in the presence of its canonical means, then he simply does not know what it means to perform that action in question, and he ignores the concepts involved here or has misunderstood them ${ }^{54}$.

When, finally, the end - considered as a precept - and the means - considered as a routine, which correctly fulfils the precept in a canonical or non-canonical manner - are submitted together in a judgement, then the relation between end and means will be again an analytical one. Hence, the judgement in question would fulfil all conditions for analyticity. - Thus, on the one hand, a type theoretical interpretation could avoid narrowness of the kind that arises when the end-means conception is conceived of as a relation of mutual analyticity. On the other hand, it would no longer be possible to deal with ends and means irrespectively of each other, that is, it would now be impossible to take the view being at the source of that slogan promoting unscrupulousness, "The end sanctifies the means ${ }^{115}$.

\footnotetext{
${ }^{51}$ This point is due to Martin-Löf [1991], p. 146: "[I]t suffices [...] to consider the case of a mathematical theorem, which is an object of knowledge, to see that the order of conceptual priority is that rightness applies primarily to the action and only derivatively to the object, because if we ask whether a theorem is correct, we certainly go to the proof, and the proof is the act or process through which we get to know the theorem, so that we have to check this act or process for its correctness and thereby arrive at the correctness of the theorem, and not the other way round".

${ }^{52}$ Cf. Jacobs [1989], p. 404.

${ }^{53} \mathrm{We}$ are concerned with fully presented or, at least, fully presentable objects in any other but the mathematical case. But even if the type of means to an end is not fully presented and probably not fully presentable, a finite amount of objects of that type is sufficiently presented to fulfil this task. Cf. Brouwer [1992], p. 22-3.

${ }^{54}$ Cf. Martin-Löf [1994], p. 90. Cf. Prawitz [1994], p. 492-3, and [1998], p. 45. Yet, it may be somewhat misleading to refer to Prawitz. For, as Prawitz does not distinguish between proof-object and proof act, he would probably not allow for a distinction between a means considered as an object (e.g., in deliberation) and the act of realising an end. See also the debate between Sundholm [1998], p. 208-9, and Prawitz [1998], p. 322.

${ }^{55} \mathrm{I}$ am grateful for valuable comments of two anonymous referees on a draft of this paper. Yet, I fear that I was not able to do justice neither to all of their legitimate requests nor to my own demands. A lot of work is left to be done. For the proofreading of the English version of this paper I am grateful to Barbara Simpson and Annette Grünig. My work was supported by the Swiss National Science Foundation (SNF).
} 


\section{REFERENCES}

ARISTOTLE, Movement of Animals, gr.-engl., in Aristotle in Twenty-Three Volumes, vol. 12, London, Heinemann, 1968.

ARISTOTLE, Ethica Nicomachea (EN), I. Bywater (ed.), $19^{\text {th }}$ ed., Oxford, Oxford University Press, 1986.

AUDI R., "Intending and Its Place in the Theory of Action", Contemporary Action Theory, Ghita Holmström-Hintikka/Raimo Tuomela (eds), vol. 1, Individual Action, Dordrecht, Kluwer, 1997, p. 177-196.

BELNAP N., PERLOFF M., XU M., Facing the Future. Agents and Choices in Our Indeterminist World, Oxford, Oxford University Press, 2001.

BITTNER R., Doing Things for Reasons, Oxford, Oxford University Press, 2001.

BRENTANO F., Vom Ursprung sittlicher Erkenntnis (1889), O. Kraus (ed.), 4th ed., Hamburg, Meiner, 1955.

BROUWER, L. E. J., Intuitionismus, Dirk van Dalen (ed.), Mannheim, Leipzig, Wien, Zürich, BI-Wissenschaftsverlag, 1992.

BURRI A., FREUDIGER J., "Zur Analytizität hypothetischer Imperative", Zeitschrift für philosophische Forschung 44, 1990, p. 98-105.

CHELLAS B. F., "On Bringing it About", Journal of Philosophical Logic 24, 1995, p. 563-571.

CURRY H. B., FEYS R., Combinatory Logic, vol. 1, with two sections by W. Craig, Amsterdam, North-Holland, 1958.

DUMMETT M., Elements of Intuitionism, Oxford, Clarendon Press, 1977.

EBERT T., "Zweck und Mittel. Zur Erklärung einiger Grundbegriffe der Handlungstheorie", Allgemeine Zeitschrift für Philosophie 2, 1977 (2), p. 21-39.

FICHTE J. G., Nachgelassene Schriften zu Platners 'Philosophische Aphorismen' (1794-1812), Gesamtausgabe II 4, R. Lauth et al. (eds), Stuttgart-Bad Cannstatt, Frommann-Holzboog, 1976.

FLEW A., "Ends and Means", The Encyclopedia of Philosophy 2, Paul Edwards (ed.), New York, Macmillan and the Free Press, 1967, p. 508-511.

FRANKFURT H. G., "On Caring", Necessity, Volition, and Love, Cambridge, Cambridge University Press, 1999, p. 155-180.

FRANKFURT H. G., The Reasons of Love, Princeton and Oxford, Princeton University Press, 2004.

GRACIÁN B., Oráculo manual y arte de prudencia (1647), Emilio Blanco (ed.), Madrid, Ediciones Cátedra, 1995.

HARMAN G., "Desired Desires", Explaining Value and Other Essays in Moral Philosophy, Oxford, Clarendon Press, 2000, p. 117-136.

HORTY J. F., Agency and Deontic Logic, Oxford, Oxford University Press, 2001.

HOWARD W., "The formulae-as-types notion of construction", in R. Hindley, J. P. Seldin (eds), To H. B. Curry: Essays on Combinatory Logic, Lambda Calculus and Formalism, London, Academic Press, 1980, p. 479-460.

HÜGLI A., "Mittel", Historisches Wörterbuch der Philosophie, vol. 5, Basel, Schwabe, 1980, p. 1431-1439.

HUSSERL E., Vorlesungen über Ethik und Wertlehre 1908-1914, U. Melle (ed.) (Husserliana vol. XXVIII), Dordrecht, Kluwer, 1988. 
JACOBS B., "The Inconsistency of Higher Extensions of Martin-Löf's Type Theory", Journal of Philosophical Logic 18, 1989, p. 399-422

JEFFREY R. C., "Preference among Preferences", The Journal of Philosophy 71, 1974, p. 377-391.

JEFFREY R. C., Logic of Decision, $2^{\text {nd }}$ ed., Chicago Ill., University of Chicago Press, 1983.

KAMBARTEL F., "Mittel", Enzyklopädie Philosophie und Wissenschaftstheorie, J. Mittelstraß (ed.), vol. 1, Mannheim/Wien/Zürich, Bibliographisches Institut, 1984, p. 903.

KANT I., Kritik der reinen Vernunft, nach der ersten und zweiten Original-Ausgabe neu hg. v. R. Schmidt, Hamburg, Meiner, 1956; engl.: Critique of Pure Reason, P. Guyer, A. W. Wood (eds), Cambridge, Cambridge University Press, 1999.

KANT I., Versuch den Begriff der negativen Größen in die Weltweisheit einzuführen, Akademie-Ausgabe, vol. 2, Berlin, de Gruyter, 1968(a), p. 165-204; engl.: Theoretical Philosophy 1755-1770, D. Walford (ed.), Cambridge, Cambridge University Press, 2003.

KANT I., Prolegomena zu einer jeden künftigen Metaphysik, die als Wissenschaft wird auftreten können, Akademie-Ausgabe, vol. 4, Berlin, de Gruyter, 1968(b), p. 253-383; engl., Prolegomena to Any Future Metaphysics, G. Hatfield (ed.), Cambridge, Cambridge University Press, 2004(a).

KANT I., Grundlegung zur Metaphysik der Sitten, Akademie-Ausgabe, vol. 4, Berlin, de Gruyter, 1968(c), p. 385-463.

KANT I., Kritik der praktischen Vernunft, Akademie-Ausgabe, vol. 5, Berlin, de Gruyter, 1968(d), p. 1-163; engl., Critique of Practical Reason, M. J. Gregor (ed.), Cambridge, Cambridge University Press, 1997.

KANT I., Metaphysik der Sitten, Akademie-Ausgabe, vol. 6, Berlin, de Gruyter, 1968(e), p. 203-494; engl.: The Metaphysics of Morals, M.J. Gregor (ed.), Cambridge, Cambridge University Press, 1996.

KANT I., Jäsche-Logik, Akademie-Ausgabe, vol. 9, Berlin, de Gruyter, 1968(f), p. 1-150; engl., Lectures on Logic, J. M. Young (ed.), Cambridge, Cambridge University Press, 2004(b).

KANT I., Foundations of the Metaphysics of Morals. Text and Critical Essays, ed. _R.P. Wolff, Indianapolis, Bobbs-Merrill, 1978.

KANT I., Grounding for the Metaphysics of Morals, Ethical Philosophy, Indianapolis, Hackett, 1983, p. 1-62.

KANT I., Groundwork of the Metaphysics of Morals, M. J. Gregor (ed.), Cambridge, Cambridge University Press, 1999.

LÖHRER G., "Gibt es analytische Urteile?", Internationale Zeitschrift für Philosophie, 2002 (1), p. 60-84.

LÖHRER G., Praktisches Wissen. Grundlagen einer konstruktiven Theorie menschlichen Handelns, Paderborn, Mentis, 2003.

MACHIAVELLI N., Discorsi sopra la prima Deca di Tito Livio (1513), libri I-II, in ders., Opere I 1, Rinaldo Rinaldi (ed), Torino, Unione Tipografico-Editrice Torinese, 1999, p. 411-943.

MACHIAVELli N., De Principatibus (1513/1532), Opere I 1, Rinaldo Rinaldi (ed), Torino, Unione Tipografico-Editrice Torinese, 1999, p. 103-409. 
MARTIN-LÖF P., "An Intuitionistic Theory of Types: Predicative Part", in H. E. Rose, J. Sheperdson (eds.), Logic Colloquium '73, Amsterdam, North-Holland, 1975, pp. 73118.

MARTIN-LÖF P., Intuitionistic Type Theory, Naples, Bibliopolis, 1984.

MARTIN-LÖF P., "A Path from Logic to Metaphysics", Atti del Congresso 'Nuovi Problemi della Logica e della scienza', G. Corsi, G. Sambin (eds.), Viareggio, 8-13 gennaio 1990, vol. II, Bologna, CLUEB, 1991, p. 141-149.

MARTIN-LÖF P., "Analytic and Synthetic Judgements in Type Theory", Kant and Contemporary Epistemology, P. Parrini (ed.), Dordrecht, Kluwer, 1994, p. 87-99.

MARTIN-LÖF P., "On the Meaning of the Logical Constants Logical Laws“, Nordic Journal of Philosophical Logic 1, 1996, p. 11-60.

MELE A. R., Springs in Action. Understanding Intentional Behavior, Oxford, Oxford University Press, 1992.

NORDSTRÖM B., PETERSSON K., SMITH J. M., Programming in Martin-Löf's Type Theory. An Introduction, Oxford, Clarendon Press, 1990.

PASCAL, B., Les Provinciales ou Les Lettres écrites par Louis de Montalto à un provincial de ses amis et aux RR. PP. Jésuits (1656), G. Ferreyrolles (ed.), Paris, Garnier, 1992.

PATZIG G., "Die logischen Formen praktischer Sätze in Kants Ethik", Ethik ohne Metaphysik, Göttingen, Vandenhoeck \& Ruprecht, 1971, p. 101-126.

PRAUSS G., Kant über Freiheit als Autonomie, Frankfurt am Main, Klostermann, 1983.

PRAUSS G., "Sind hypothetische Imperative analytische praktische Sätze?", Grundlegung zur Metaphysik der Sitten. Ein kooperativer Kommentar, O. Höffe (ed.), Frankfurt am Main, Klostermann, 1989, p. 148-171.

PRAWITZ D., "Quine on Verificationism", Inquiry 37, 1994, p. 487-494.

PRAWITZ D., "Truth and objectivity from a verificationist point of view", Truth in Mathematics, H. G. Dales, G. Oliveri (eds), Oxford, Clarendon Press, 1998, p. 41-51.

PRAWITZ D., "Comments on the Papers", Theoria 64, 1998, p. 283-337.

QUINE W. V., Word and Object, $12^{\text {th }}$ ed., Cambridge MA, MIT Press, 1981.

RANTA A., "Propositions as Games as Types", Synthese 76, 1988, p. 377-395.

RANTA A., Type-Theoretical Grammar, Oxford, Clarendon Press, 1994.

SCHICK F., Understanding Actions. An Essay on Reasons, Cambridge, Cambridge University Press, 1991.

SCHICK F., Making Choices. A Recasting of Decision Theory, Cambridge, Cambridge University Press, 1997.

SCHWEMMER O., "Zweck", Enzyklopädie Philosophie und Wissenschaftstheorie, J. Mittelstraß (ed.), vol. 4, Stuttgart, Metzler, 1996, p. 865-868.

SEARLE J. R., Rationality in Action, Cambridge MA, A Bradford Book - MIT Press, 2001.

SEEL G., "Sind hypothetische Imperative analytische praktische Sätze?“, Grundlegung zur Metaphysik der Sitten. Ein kooperativer Kommentar, O. Höffe (ed.), Frankfurt am Main, Klostermann, 1989, p. 148-171.

SEGERBERG K., "Routines", Synthese 65, 1985, p. 185-210.

SEGERBERG K., "Bringig It About", Journal of Philosophical Logic 18, 1989, p. 327347. 
SEGERBERG K., "The Delta Operator at Three Levels of Analysis", Logic, Action, and Information. Essays on Logic in Philosophy and Artificial Intelligence, André Fuhrmann, Hans Rott (eds), Berlin/New York, de Gruyter, 1996, p. 63-75.

SEHON S., "Teleology and the Nature of Mental States", American Philosophical Quarterly 31, 1994, p. 63-72.

SMITH M., The Moral Problem, Oxford, Blackwell, 1994.

SOMMARUGA G., History and Philosophy of Constructive Type-Theory, Dordrecht, Kluwer, 2000.

STAMPE D. W., "The Authority of Desire", The Philosophical Review 96, 1987, p. 335-381.

SUNDHOLM, G., "Proofs as Acts and Proofs as Objects: Some Questions for Dag Prawitz", Theoria 64, 1998, p. 187-216.

WILSON G., The Intentionality of Human Action, Stanford, Stanford University Press, 1980 . 